переводить кінцеві цінності суспільної культури в царину нової суспільної свідомості, що формується, і таким способом здійснює вплив на процеси, що відбуваються в духовному житті, економіці, політиці.

У школі, на уроці учень повинен знайти цінності, вибрати їх для себе, співвіднести з уже відомими, при чому точно визначитися у їх значенні для реалізації у житті. Щоб бути впевненим у досягненні вчителем своїх цілей, щодо застосовування їх школярами на практиці, урок повинен за допомогою спеціальних умов допомогти учням знайти сенси. «Набуття сенсів - сутність буття. Людина не вигадує сенсів, вона їх знаходить з-поміж цінностей життя» [2, с. 3].

Отже, як науковці XVII-XIX століть, так і сучасні дослідники вказують на ефективність навчання у тому випадку, коли створюються умови для взаємопроникнення глибинного й істотного мислення, що забезпечує в такому синтезі формування й подальший розвиток ціннісно-смислової свідомості школярів.

\title{
Література
}

1. Бичко А. К. Історія філософії : [підручник] / А. К. Бичко, І. В. Бичко, В. Г. Табачковський. К. : Либідь, 2001. - 408 с. 2. Бондаревская Е. В. Учителю о личностно ориентированном образовании / Е. В. Бондаревская // Воспитание как встреча с личностью. - Т. 2, Ростов-на-Дону, 2006. - 502c. 3. Каган М. С. Философская теория ценности / М. С. Каган. - СПб, 1997. - 215 с. 4. Каптерев П. Ф. Общечеловеческие идеалы в теории средней школы. Педагогика Н. И. Пирогова / П. Ф. Каптерев // Педагогика. - 1995. - № 5. - С. 64-75. 5. Сластенин В.А. Педагогика / В. А Сластенин, И. Р. Исаев, Е. И. Шиянов - М. : Академия, 2002. - 406 с. 6. Філософія: [підручник] [за заг. ред. Горлача М. І., Кременя В. Г., Рибалка В. К.]. - Харків : Консум, 2000. - 672 с. 7. Філософія: [навчальний посібник] / I. Ф. Надольний, В.П.Андрущенко, І І. В. Бойченко, В. П. Розумний та ін.; за ред. І. Ф. Надольного. - К. : Вікар, 1997. - 584 с. 8. Шамова Т. И. Управление образовательными системами / Т. И. Шамова, Т. М. Давыденко, Г. Ј. Шибанова. - М. : Академия, 2002. - 312 с. аспірант, Інститут педагогіки НАПН України

\section{ПОЄДНАННЯ ІНТЕЛЕКТУАЛЬНОГО ТА ЕМОЦЙНОГО АСПЕКТІВ У ПРОЦЕСІ ОВОЛОДІННЯ ПРИРОДОЗНАВЧОЮ ОСВІТОЮ УЧНЯМИ ОСНОВНОЇ ШКОЛИ ЯК ЗДОРОВ'ЯЗБЕРІГАЛЬНИЙ ЧИННИК}

Дишлева I. M. Поєднання інтелектуального та емоційного аспектів у процесі оволодіння природознавчою освітою учнями основної школи як здоров'язберігальний чинник.

У статті розкрито принципи природознавчої освіти, застосування яких сприяє досягненню оптимального поєднання інтелектуальних й емоційних якостей особистості учнів як здоров'язберігального чинника.

Ключові слова: природознавча освіта, інтелектуальні якості, емоційні якості, учні основної школи, здоров'язберігальний чинник.

Дышлева И. М. Сочетание интеллектуального и эмоционального аспектов в процессе овладения учащимися основной школы естественонаучным образованием как здоровьесохраняющий фактор.

В статье раскрыты принципы природоведческого образования, применение которых способствует достижению оптимального объединения интеллектуальных и эмоциональных качеств личности учеников как здоровьесберегающий фактор.

Ключевые слова: природоведческое образование, интеллектуальные качества, эмоциональные качества, ученики основной школы, здоровьесберегающий фактор.

Dyshleva I. M. Combination of intellectual and emotional aspects of students of basic school in the process of study of science education as preserving health factor. 
In the article the principles of Natural History Education, the use of which contributes to the optimal combining intellectual and emotional qualities of the individual students as health promoting factor.

Key words: natural history education, intellectual qualities, emotional quality, primary school students, health-factor.

Розвиток соціокультурного процесу в державі визначається суперечливим поєднанням тенденцій збереження і розвитку, у якому особистість і суспільство $€$ необхідною умовою процесу розвитку, ускладнення, удосконалення. Одним із найважливіших важелів впливу на соціокультурні процеси, що відбуваються в Україні, має стати природознавча освіта. Забезпечуючи цілеспрямоване передавання вітчизняних і регіональних культурних надбань, вона $\epsilon$ ефективним засобом соціалізації підростаючого покоління, від якого залежить характер розвитку соціального життя в країні.

Дослідниками попередніх етапів розвитку освіти накопичений певний науковий та емпіричний досвід щодо розгортання, тенденцій розвитку та вивчення організаційно-педагогічних форм викладання природознавства, організації освітньо-краєзнавчої роботи.

Предметом спеціальних досліджень стали окремі аспекти природознавчої і краєзнавчопошукової роботи, зокрема: умови формування патріотизму засобами шкільного краєзнавства (І. Прус); роль краєзнавчо-пошукової роботи у підготовці учнів до праці і вибору професії (С. Бабашин); формування пізнавальної самостійності учнів у процесі дослідження рідного краю (А. Хоптяр); вплив творчої роботи у процесі вивчення природи рідного краю на формування духовних якостей особистості (М. Дуденко); екологічні аспекти експедиційної діяльності 3 охорони природи рідного краю (Г. Пустовіт) та інші.

Водночас питання досягнення балансу інтелектуальних й емоційних якостей учнів у процесі оволодіння природознавчою (краєзнавчою) освітою не знайшла грунтовного висвітлення.

Meта статті - розкрити принципи побудови природознавчої освіти в основній школи, що забезпечують оптимальне поєднання інтелектуальних та емоційних якостей як здоров'язберігальний чинник.

Природнознавча освіта становить процес і результат цілеспрямованого формування особистості на основі засвоєння досвіду і традицій вітчизняної і регіональної (краєзнавчий аспект) культури.

Природознавча (краєзнавча) освіта, стимулюючи одержання конкретними індивідами i людськими спільнотами єдиних суспільно-державних якостей, сприяє утворенню:

вітчизняних i регіонально-соціумних цілісностей, в яких у процесі формування людської особистості органічно поєднуються іiі соціокультурне вітчизняне, регіонально-соціумне та індивідуально-групове (етнічно-особистісне) становлення, що безпосередньо є стабілізаційнодинамізаційним чинником консолідації етносу;

вимога усебічного розвитку людини як особистості ставить питання про охоплення природознавчою (краєзнавчою) освітою всіх основних складників вітчизняної і регіональної соціально-культурної спадщини. Тобто йдеться про розвиток усіх видів діяльності, що складають структуру особистості - діяльності перетворювальної, пізнавальної, цілісно-орієнтаційної, спілкування, художньої [2].

Отже, природознавча (краєзнавча освіта) - як загальна - має поєднувати всі види елементів регіональної культури, що визначають основні види діяльності. 3 цих позицій завдання природознавчої (краєзнавчої) освіти нині полягає у досягненні пропорційного, збалансованого, рівноправного співіснування всіх іiі складників за принципом взаємодоповнюваності інтелектуальних й емоційних якостей.

Така комплексність для загальної природознавчої (краєзнавчої) освіти має забезпечуватись обов'язковим рівнозначним представництвом у ії змісті кожного $з$ основних компонентів. Комплексне урівноваження видових складників природознавчої (краєзнавчої) освіти має поєднуватись із приведенням педагогічних технологій і оцінок у відповідність до основних освітніх компонент.

Природознавча (краєзнавча) освіта, створюючи умови для повноцінного розвитку людських індивідів, є багатогранним соціально-освітнім явищем і невід’ємною складовою гуманітарної освіти.

Утворення і розвиток будь-якої системи спрямовується на те, щоб шляхом іiі доцільної організації та постійного удосконалення функцій іiї складових досягти підвищення ефективності поставлених цілей. 
Відповідно до теорії систем функціональні аспекти в цілому освітянської галузі (функціональний склад освіти, поєднання функцій, їх системоутворювальна повнота тощо) розроблялися Е. Білозерцевим, О. Коопом, Н. Кузьміною, Ф. Філіповим, В. Луговим та іншими.

Як показав розгляд історико-типологічних аспектів природознавства (українського краєзнавства), основні функції природознавчої (краєзнавчої) освіти, завдяки яким вона виникла i розвивається як самостійний культурно-освітній напрям у складі освітянської галузі, слід виводити як з умов і потреб соціокультурного життя суспільства, так і конкретного регіону.

3 першою головною тенденцією розвитку природознавчої (краєзнавчої) освіти (яка полягає у використанні ії можливостей з метою гармонізації відносин освіти з суспільством, людиною, природою, культурою) пов'язана реалізація іiі зовнішньої функції, спрямованої на забезпечення відродження і посилення життєвої відповідності освітньої сфери.

Урахування зазначеної тенденції підвищує роль природознавчої (краєзнавчої) освіти, що забезпечує досягнення гармонії інтелектуальних й емоційних якостей особистості учнів як здоров'язберігальний чинник відповідно до:

- Принципу суспільствовідповідності, відповідно до якого реалізується суспільноорганізаційна функція освіти, спрямована на забезпечення соціально-необхідної регіональної культури особистості. Освітній напрям визначає соціально-інтегрувальну функцію природознавчої (краєзнавчої) освіти, яка спрямована на збереження цілісності суспільства, (зокрема шляхом розвитку особистості відповідно до норм та цінностей (державно-політичних, моральноконфесійних, етнічно-світоглядних тощо) вітчизняної й конкретної регіональної культури.

Зауважимо, у краєзнавстві закладено той освітньо-виховний потенціал, який має бути спрямований на розкриття культурно-історичної й державно-політичної унікальності України, у зв'язку з чим стає доцільним вивчення української етнічної території за історико-географічними регіонами (краями), в основу виокремлення яких покладено природно-матеріальний, культурноісторичний і етнографічний принципи.

- Принщипу культуровідповідності, відповідно до якого реалізується функція передавання соціокультурних надбань національної (регіональної) культури суб'єкту і встановлюється адекватність природознавчої (краєзнавчої) освіти тій регіональній культурі, складником якої вона $\epsilon$.

Принцип культуровідповідності освіти розроблявся Я. Коменським, А. Дістервегом, К. Ушинським, Г. Сковородою, В. Сухомлинським та іншими.

Природознавча (краєзнавча) освіта, забезпечуючи освітньо-культурними засобами соціальне успадкування національного (регіонально-культурного) досвіду, спрямована на задоволення потреб, які пов'язані із зміцненням і удосконаленням конкретного соціального організму країни (регіону). Це означає, що збереження цілісності суспільства і злагоди у ньому здійснюється, в першу чергу, через розвиток кожного індивідуума відповідно до норм, ідеалів, цінностей і стереотипів конкретного регіону, його соціальної системи.

Природознавча (краєзнавча) освіта, здійснюючи психічно-духовний вплив на індивіда, спрямована на формування у його свідомості певного рівня суспільно-нормативних (релігійних, моральних, естетичних тощо) і особистісних потреб, відповідно до чинних норм країни та регіону. Тому в інтересах як держави заалом, так і іiі конкретних регіонів стає необхідною передавання підростаючому поколінню стереотипізованого історично-культурного досвіду і формування відповідної соціокультури особистості.

При цьому загальноукраїнський фон культурно-освітянських традицій залишається відкритим для збагачення як зовнішнім загальнолюдським, так і внутрішнім етнонаціональним.

- Принципу людиновідповідності, відповідно до якого реалізується функиія індивідуального окультурення людини, спрямована на врахування інтересів як окремих соціальних груп, так i намагання кожного індивіда одержати відносну самостійність і самовизначення, а в кінцевому підсумку - до морального становлення як особистості, іiї громадянської зрілості. У такий спосіб виявляється ознака природознавчої освіти, як їі людиновідповідність, тобто природознавча освіта, 3 одного боку, сприяючи оволодінню індивідом соціоально досвідом, виконує суспільностабілізаційну функцію, з іншого, - здійснюючи на основі опанування цього досвіду повноцінне включення індивіда у суспільне життя, виконує соціалізаційну функцію по відношенню до конкретної людини;

- Принципу природовідповідності, відповідно до якого реалізується функиіл культурного удосконалення фізичних якостей індивіда та функиіл розвитку соиіально-значущих природних задатків людини, спрямована на гармонійну взаємодію людини і суспільства 3 природним середовищем (тенденції 
розвитку екологічної освіти, удосконалення фізичної культури, врахування в освіті природних задатків людини тощо).

Принцип природовідповідності у навчанні і вихованні, як надбання педагогічної системи в процесі ії розвитку, обгрунтовувався Я. Коменським, А. Дістервегом, Г. Сковородою, Л. Толстим, М. Максимовичем, В. Сухомлинським.

Відповідно до вказаного принципу у природознавчій (краєзнавчій) освіті реалізуються: екологічна функиія освіти та виховання; освітня функиія культурного удосконалення фізичних якостей та природних задатків людини.

Культура особистості учня набуває рис соцоікультури країни й регіону, і починає здійснювати певний вплив на довкілля. В цьому випадку природознавча (краєзнавча) освіта зокрема виконує продуктивно-результативну функцію, характеристики якої слід розглядати у системі, до складу якої вона входить, потребами, структурою і розвитком якої вони зумовлюються [1, с. 22-23].

Природознавчу (краєзнавчу) освіту слід розглядати через іiі зв'язки з середовищем, по відношенню до якого вона функціонує, тобто через зв'язки з суспільством, людиною, природою, культурою, освітою взагалі. Саме такий підхід дозволяє розглядати природознавчу (краєзнавчу) освіту як закономірно організовану багаторівневу систему, функціонування якої забезпечує досягнення гармонії інтелектуальних й емоційних якостей особистості учнів як здоров'язберігальний чинник.

\section{Література}

1. Каган М. С. Системный подход и гуманитарное знание : Избранные статьи / М.С. Каган. Л. : Изд-во Ленин. ун-та,1991. - 384 с. 2. Луговий В. І. Педагогічна освіта в Україні / В. І. Луговий. - К. : МАУП, 1994. - 196 с.

УДК 372.8:004+378.147

М. В. Золочевська, кандидат пед. наук, доцент, К3 «Харківська гуманітарно-педагогічна академія»

\section{МЕТОДИ ТА ПРИЙОМИ РОБОТИ НАД ПОНЯТТЯМИ НА УРОКАХ ІНФОРМАТИКИ}

Золочевська М. В. Методи та прийоми роботи над поняттями на уроках інформатики.

Робота над поняттями є важливим складником дослідницької діяльності, що зумовлює навчання учнів виокремлювати основні поняття предметної області, аналізувати наявні трактування, конструювати поняття на основі істотних ознак. У статті пропонуються методи та прийоми активного навчання роботи з понятійним апаратом на уроках інформатики.

Ключові слова: конструювання понять, методи активного навчання, уроки інформатики.

Золочевская М. В. Методы и приемы работы над понятиями на уроках информатики.

Работа над понятиями является важной составляющей исследовательской деятельности, что обуславливает необходимость обучения выделять основные понятия предметной области, анализировать существующие трактовки, конструировать понятия на основе существенных признаков. В статье предлагаются методы и приемы активного обучения работе с понятийным аппаратом на уроках информатики.

Ключевые слова: конструирование понятий, методы активного обучения, уроки информатики.

Zolochevska M.V. Methods for working teaching how to work with concepts on the lessons of informatics.

Work on concepts is important component of research activity, that's why it's so important for teachers and professors to teach young men to choose main concepts of domain, analyse existing treatments, build concepts based on essential characteristics etc. In the article different methods of teaching how to work with concepts are suggested to the teachers of informatics.

Key words: the building concepts, the methods of active teaching, lessons of informatics.

Навчання через дослідження в контексті виховання обдарованої дитини набуває поширення. Інтенсивно ведуться пошуки шляхів удосконалення процесів навчання та розвитку людини на основі навчання через дослідження, про що свідчать роботи Т. Сгорової, І. Ільницької, М. Кларіна, А. Леонтовича, А. Обухова, О. Подд’якова, 